\title{
Development of Interactive Multimedia to Improve Student's Understanding on Carbonyl Compounds Reaction Mechanism Concept
}

\author{
Ii Ishak Fauzi, Neneng Windayani*, Citra Deliana Dewi Sundari \\ Department of Chemistry Education \\ UIN Sunan Gunung Djati Bandung \\ Bandung, Indonesia \\ iiishakfauzi@gmail.com, *nenengwinda.ftk@uinsgd.ac.id, citra@uinsgd.ac.id
}

\begin{abstract}
Student's understanding of the mechanism reaction of carbonyl compounds needs to be developed using interactive multimedia. Thus, the research was carried out using a DesignBased Research (DBR) method. This research phase consists of analysis, design, and development stages. Overall validation test results obtained $r$ count of 0.83 and declared valid. While the feasibility test results obtained the feasibility percentage of 88.1\%. This percentage shows that interactive multimedia on the mechanism reaction of carbonyl compounds is feasible as a learning medium.
\end{abstract}

Keywords-carbonyl compounds, chemical representation, interactive multimedia, mechanism reaction

\section{INTRODUCTION}

Chemistry is basically about abstract material that can be described at various levels [1]. In its development, chemistry is emphasized at three levels of representation, namely macroscopic, submicroscopic, and symbolic [2]. Three levels of representation of a material in chemistry learning are depicted in real phenomena that are familiar with students, such as models, equations, graphs, diagrams, simulations, and images used to help describe ideas so that they are more real and easily understood [1].

Although it is very interesting to learn, students have difficulty in connection the three levels of representation in the learning process of chemistry. Studying abstract concepts with concrete examples is difficult to understand even though it can be observed in a laboratory [3]. Abstract concepts in the submicroscopic level can only be reached by imagination [4], so that if the submicroscopic level cannot be understood and represented properly, it will hamper the ability to solve problems related to macroscopic phenomena and symbolic representations [5].

One discussion that requires the ability to interconnection three levels of representation is the mechanism reaction of carbonyl compounds. Many students are still confused in learning the reaction mechanism reaction of carbonyl compounds, such as understanding in the picture of mechanism reactions, arrows, curved lines and so on [6]. In addition, the mechanism reaction of carbonyl compounds is very important to understand, because carbonyl compounds that are often used in daily life, for example, used as solvents, fabric dyes, flavorings in food, plastics, and medicines. Carbonyl compounds are also one of the basic compounds making up protein, carbohydrates, and nucleic acids [7]. In fact, most biological molecules contain carbonyl groups [8].

Phenomena related to the mechanism reaction of carbonyl compounds require understanding by connecting the three levels of representation, because a chemical study if explored only uses transformation from the macroscopic level to the symbolic or otherwise, the students will be less aware of the submicroscopic level [9]. Because of this, we need a media that can connect the three levels of chemical representation, one of which utilizes technological developments today.

The development of science and technology which is increasingly rapid encouraging efforts to use technology in the learning process, namely the use of technology-based learning media [10]. The use of technology as a medium has increased as a model of learning that is widely practiced in modern times [11].

The use of multimedia in learning will also motivate students to learn, they can see visuals (animation or text) and listen to audio simultaneously [12]. The ability to remember consists of visual text (pictures) $40 \%$, audio $10 \%$, and audiovisual (animation) 50\%, which means a person's memory will last for a longer period of time if the media used is a combination of audio and visual called the audiovisual (animation) [13].

Interactive multimedia is one alternative way in solving the problem of using a learning media that does not support the interaction and control of the learning process [14], because interactive multimedia must contain goals, content, navigation, hyperlinks, and learning interfaces [12]. Media visual animation (visualization) made interactive also allows students 
to change input variables by manipulating visual objects, and can observe changes in visualization itself [15].

The use of multimedia has been widely carried out in various chemistry materials, such as interactive multimedia on alcohol reactions by Hidayaturrohman [16]. Based on his research, the average response to agree to the use of multimedia is $90,22 \%$. The same thing was also seen in the research on animation-based interactive multimedia development on the basic material of corrosion and coating by Sugiarto [13]. The results showed that multimedia was very feasible to use and student responses reached a score of $82,2 \%$ (good). Learning outcomes also increased from $40 \%$ to $73,91 \%$.

Although it has been developed and used in various studies, the development of interactive multimedia still needs to be refined again. One of them is in submicroscopic level display, which is still using 2D display. With 3D display, media can be understood easily and look more alive [17]. Therefore, interactive multimedia will be easier to improve the ability to connect the three levels of representation.

This research aims to describe the appearance and analyze the feasibility of interactive multimedia products on the mechanism reaction of carbonyl compounds.

\section{Methods}

This research method used was the Design-Based Research (DBR) method. This method is based on the development of educational study and technology designed to support the learning process, so that a product can be used to help students in the learning process [18]. Design-Based Research is research method based on technology that supports the learning process with several stages used, namely analysis, design, development, implementation and evaluation [19]. However, the stages in this research were only carried out at the analysis, design and development stage, while the implementation and evaluation stages were not carried out. This is because interactive multimedia that is made has not yet been fully implemented so the evaluation results cannot be determined yet.

\section{A. Analysis Stage}

At the analysis stage, there are several things that need to be prepared, including analyzing concepts, making concept maps, determining indicators of learning achievement, and determining supporting software needed in making interactive multimedia.

\section{B. Design Stage}

At the design stage, a flowchart and storyboard are made as the beginning of the design of interactive multimedia which contains a basic picture and the steps of the interactive multimedia operation.

\section{Development Stage}

At the development stage, interactive multimedia creation is carried out which contains learning material in the form of 3D animation, writing, visual and audio in accordance with the flowchart and storyboard that have been made.

After interactive multimedia is created, then testing is done in the form of product assessment, namely the validation test of multimedia that has been made. Product evaluation was validated by material expert lecturers and multimedia expert lecturers using a validation questionnaire. Responses and suggestions from the validation results are used as a reference for revising multimedia so that a final interactive multimedia product is obtained. The final interactive multimedia that has been improved is conducted a feasibility test or limited trial to students using a limited trial questionnaire. Then, the data generated from the limited trials were analyzed and conclusions were drawn about the feasibility of the interactive multimedia mechanism of the reaction.

Data acquisition to find out the validation of interactive multimedia is done by using the validation test instrument. The validation test instrument in the form of a questionnaire containing statements that must be marked with a checklist in accordance with the existing score. The results of filling out the questionnaire from all validators are summed to find out the overall total score. The results of this data in the form of the calculated $r_{\text {value }}$ can be compared with the critical $r_{\text {value }}$ of 0,3 . If the value of $r$ count for each validity exceeds the value of critical $r\left(r_{\text {count }}>r_{\text {count }}\right)$ then the criteria item is declared valid. However, if the value of $r$ count for each validity does not exceed the critical value of $r\left(r_{\text {count }}>r_{\text {count }}\right)$ then the item criteria are declared invalid [20]. The formula used to determine the validity value $(r)$ is:

$$
r=\frac{x}{N \cdot n}
$$

\section{Information:}

$\mathrm{r} \quad=$ the value of validity

$\mathrm{X}=$ total number of respondents' answers

$\mathrm{N}=$ the maximum score

$\mathrm{n} \quad=$ total number of respondents

The acquisition of data in knowing the feasibility of interactive multimedia is carried out using a feasibility test instrument. The instrument is in the form of a questionnaire containing statements that must be marked with a checklist according to the existing scores. In the quantitative calculations used which are adjusted to the number of the score, the percentage of eligibility is obtained. The percentage of eligibility results of the feasibility test questionnaire can be calculated using the formula [21]:

$$
\%=\frac{\Sigma n}{N} \times 100 \%
$$




\section{Information:}

$\%=$ percentage of eligibility

$\sum \mathrm{n}=$ total number of respondents' answers

$\mathrm{N} \quad=$ total number of respondents

\section{RESULTS AND DISCUSSION}

At the development stage of interactive multimedia products on the mechanism reaction of the carbonyl compound is done by using some software by integrating text, visual and audio into multimedia based on a flow chart and storyboard that have been made. Interactive multimedia display containing hyperlinks that connect between slides. Besides that, on each main slide, the titles and images of 3D molecular compounds of carbonyl and audio back sound accompany the use of interactive multimedia. In the main menu view, there are buttons leading to the introductory slide, objectives, material studies, evaluation, about, and exit buttons. See Figure 1.

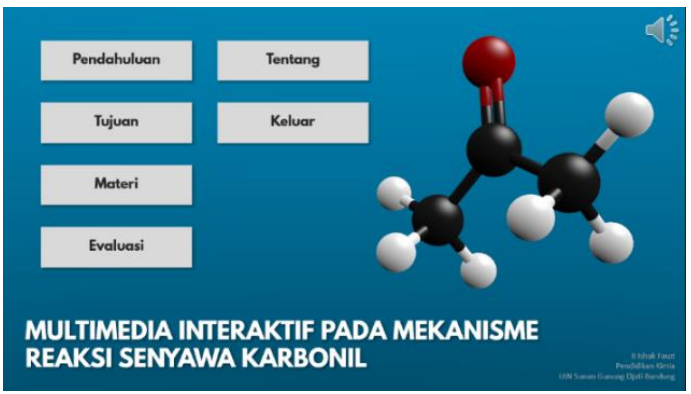

Fig. 1. Display the interactive multimedia main menu.

The material studies display informs the user about the general material and the main the general material and the main principles of the reaction of the carbonyl compound. In addition, it also contains questions that lead to the material and answers to these questions. Sub material studies presented include nucleophilic addition reactions, carbonyl reduction reaction, carbonyl oxidation reactions, and aldol condensation reactions. Display material studies od mechanism reaction contains the stages of each mechanism reaction of carbonyl compounds and displays a 3D animation of these stages (See Figures 2, 3, 4).

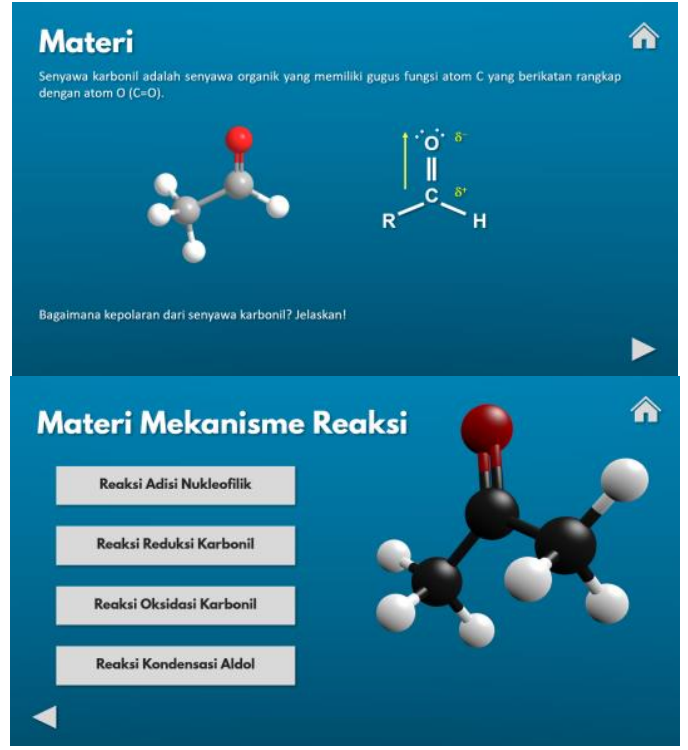

Fig. 2. Display of interactive multimedia material studies.

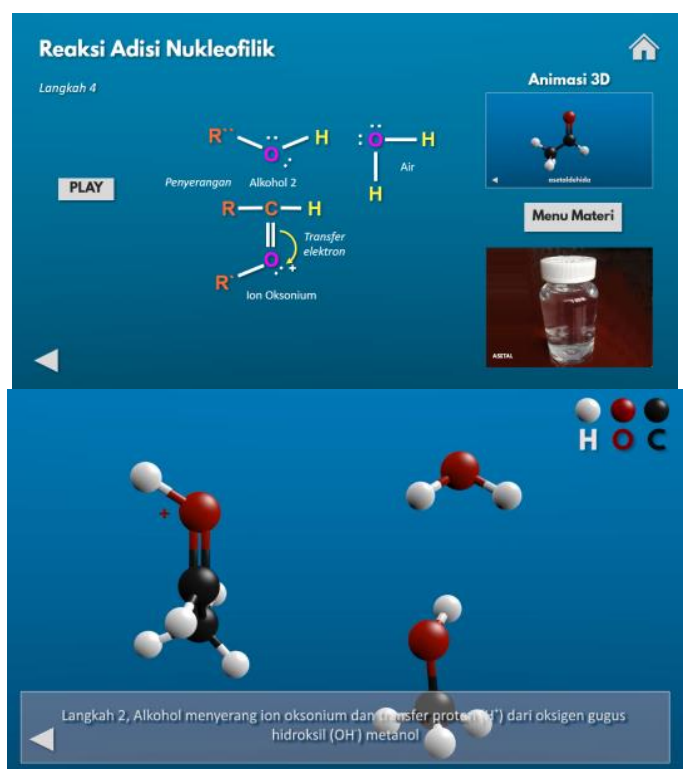

Fig. 3. Display material studies mechanism reaction of carbonyl compounds.

In addition, interactive multimedia also displays slides which contain evaluation of learning. The slide contains evaluation questions with 4 answers to choose from. If the selected answer is correct, the 'Jawaban Benar!' statement will appear, while if the answer is wrong the 'Jawaban Salah!' will appear. 


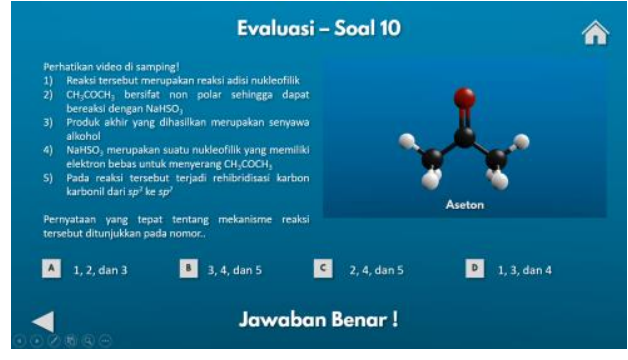

Fig. 4. Display evaluation mechanism reaction of carbonyl compounds.

Validation test results that have been calculated using the equation (1) yielded average validation results in all aspects of all validators. Based on Table 1, the average count obtained for each aspect is 0.81. According to Sugiyono [20] states that the media can be said to be valid if it has a count of more than 0.3 . In general, interactive multimedia on the mechanism reaction of carbonyl compounds is declared valid.

TABLE I. AVERAGE VALIDATION RESUlTS ON THE CONTENT, LEARNING, AND INTERACTIVE MULTIMEDIA DISPLAY ASPECTS

\begin{tabular}{|l|l|l|l|}
\hline \multicolumn{1}{|c|}{ Aspects } & $\begin{array}{c}\text { Average } \\
\text { Validation Results }\end{array}$ & $\boldsymbol{r}_{\text {count }}$ & Explanation \\
\hline Content Aspects & 0.80 & 0.3 & Valid \\
\hline $\begin{array}{l}\text { Learning } \\
\text { Aspects }\end{array}$ & 0.79 & 0.3 & Valid \\
\hline Display Aspects & 0.83 & 0.3 & Valid \\
\hline Average & 0.81 & Valid \\
\hline
\end{tabular}

The results of the due diligence were calculated using the equation (2) the resulting average test results are limited with several indicators. Based on Table 2, overall multimedia on the mechanism reaction of carbonyl compounds is included in the feasible category with an average percentage of $88.1 \%$. According to Sudjana [21] interactive multimedia with a percentage of eligibility of $80-89 \%$ declared feasible to use.

TABLE II. AVERAGE INTERACTIVE MUlTimedia LiMITED TRIAL RESULTS

\begin{tabular}{|l|l|l|l|l|}
\hline \multicolumn{1}{|c|}{ Indicator } & $\begin{array}{l}\text { Question } \\
\text { Number }\end{array}$ & Score & $\begin{array}{c}\text { Criterion } \\
\text { Score }\end{array}$ & $\begin{array}{c}\text { Percentage } \\
(\%)\end{array}$ \\
\hline $\begin{array}{l}\text { Relevance to } \\
\text { the learning } \\
\text { objectives }\end{array}$ & $\begin{array}{l}1,6,13,16 \\
14,178\end{array}$ & 200 & 89.0 \\
\hline $\begin{array}{l}\text { Efficiency of } \\
\text { use }\end{array}$ & 2 & 36 & 40 & 90.0 \\
\hline $\begin{array}{l}\text { Effectiveness } \\
\text { of use }\end{array}$ & 3,19 & 72 & 80 & 90.0 \\
\hline Flexibility & 8,12 & 68 & 80 & 85.0 \\
\hline $\begin{array}{l}\text { Media } \\
\text { display }\end{array}$ & $4,9,11$ & 110 & 120 & 91.7 \\
\hline $\begin{array}{l}\text { Increase } \\
\text { motivation }\end{array}$ & $5,18,20$ & 104 & 120 & 86.7 \\
\hline $\begin{array}{l}\text { Encourage to } \\
\text { learn }\end{array}$ & $10,15,7$ & 105 & 120 & 87.5 \\
\hline $\begin{array}{l}\text { Other media } \\
\text { development } \\
\text { prospects }\end{array}$ & 17 & 34 & 40 & 85.0 \\
\hline Average percentage & & & 88.1 \\
\hline
\end{tabular}

\section{CONCLUSION}

Appearance of learning media has interactive characteristics, facilitating the animation of the mechanism reaction of the carbonyl compound, so that the user can build an understanding of the mechanism reaction of carbonyl compound. The results of the feasibility test indicate that interactive multimedia products on the mechanism reaction of carbonyl compounds are suitable for use as learning media.

\section{ACKNOWLEDGMENTS}

We thank to LP2M UIN Sunan Gunung Djati Bandung who has funded so that this research can take place.

\section{REFERENCES}

[1] G. Chittleborough, "Learning with Understanding in the Chemistry Classroom," Springer, Dordrect, pp. 25-40, 2014.

[2] I. Farida, "The Importance of Development of Representational Competence in Chemical Problem Solving Using Interactive Multimedia," Proceeding Third Int. Semin. Sci. Educ., no. October, pp. 259-277, 2009.

[3] F. Irwansyah, I. Ramdani, and I. Farida, "The development of an Augmented Reality (AR) technology-based learning media in metal structure concept," Ideas 21 st Century Educ., pp. 233-237, 2017

[4] B. Bucat and M. Mocerino, "Multiple Representations in Chemica Education," vol. 4, 2009.

[5] R. Kozma and J. Russell, "Students Becoming Chemists: Developing Representationl Competence," Vis. Sci. Educ., pp. 121-145, 2005.

[6] G.L. Patrick, Instant Notes - Organic Chemistry, 2nd ed. New York: BIOS Scientific Publishers, 2004.

[7] L.G. Wade, Organic Chemistry (6 Ed.), VI. USA: Pearson Prentice Hall, 2006

[8] J.E. McMurry, Organic Chemistry, Ninth. United States of America: Chengage Learning, 2016

[9] I. Farida, Liliasari, and W. Sopandi, "Pembelajaran Berbasis Web untuk Meningkatkan Kemampuan Interkoneksi Multiplelevel Representasi Mahasiswa Calon Guru pada Topik Kesetimbangan Larutan Asam-Basa The Implementation of web-based Learning to Enhance Interconnection of Multiple Levels of Repres," J. Chem., vol. 12, pp. 14-24, 2011.

[10] A. Agustina, "Pembelajaran Konsep Ikatan Kimia dengan Animas Terintegrasi Lcd Projector Layar Sentuh (Low Cost Multi Touch White Board," J. Tadris Kim., vol. 1, no. 1, p. 8, 2017.

[11] R.C. Fortenberry, A.R. McDonald, T.D. Shepherd, M. Kennedy, and C.D. Sherrill, "PSI4Education: Computational Chemistry Labs Using Free Software,” ACS Symp. Ser., vol. 1193, pp. 85-98, 2015.

[12] A.T. Ampa, "The Implementation of Interactive Multimedia Learning Materials in Teaching Listening Skills," English Lang. Teach., vol. 8, no. 12 , p. 56, 2015.

[13] H. Sugiarto, "Pengembangan Multimedia Interaktif Berbasis Animasi untuk Siswa SMK dalam Proses Dasar Perlakuan Logam Kompetensi Korosi dan Pelapisan," Universitas Pendidikan Indonesia, 2016.

[14] D. Zhang, "Interactive Multimedia- Based E-Learning: A Study of Effectiveness," Am. J. Distance, no. October 2014, pp. 37-41, 2010.

[15] H. Tambunan and E. Napitupulu, "Effectiveness of Interactive Multimedia Based Learning Model in Engineering Mechanics," Can. Cent. Sci. Educ., vol. 9, no. 10, pp. 155-162, 2016.

[16] M. Hidayaturohman, "Pembuatan Multimedia Interaktif berorientas Tiga Level Representasi pada Reaksi Alkohol," UIN Sunan Gunung Djati Bandung, 2016. 
[17] N.A. Prastyo, "Pembuatan Video Profil Tiga Dimensi (3D) Sentra Ponsel Kudus," Speed - Sentra Penelit. Eng. dan Edukasi, vol. 2, no. 4, pp. 54-59, 2011.

[18] T. Anderson and J. Shattuck, "Design-based research: A decade of progress in education research?," Educ. Res., vol. 41, no. 1, pp. 16-25, 2012 .
[19] J. Herrington, S. McKenney, T. Reeves, and R. Oliver, "Design-based research and doctoral students: Guidelines for preparing a dissertation proposal," World Conf. Educ. Multimedia, Hypermedia Telecommun., vol. 2007, no. 2007, pp. 4089-4097, 2007.

[20] Sugiyono, Metode Penelitian Kuantitatif, Kualitatif dan RnD. Bandung: Alfabeta, 2017.

[21] Sudjana, Metode Statistika. Bandung: Tarsito, 2009 